\title{
Composition of bacterial communities isolated from core samples taken from petroleum deposits
}

\begin{abstract}
Microbial communities in the subterranean environment are unique in that they are completely isolated from biological communities that rely on photosynthesis, earth's atmosphere or oceans. Interestingly, bacteria found in petroleum deposits are often in a dormant form because petroleum deposits are very limited in nitrogenous and phosphorous-containing nutrients. These are unique populations as compared to other subsurface microbial communities and might consist of novel species, new metabolic capabilities, and undiscovered adaptive microbial mechanisms. The goal of the current study was to isolate and identify cultivable bacteria (mainly oligotrophs) and develop a method to evaluate bacterial community structure in petroleum deposits using $16 \mathrm{~S}$ rDNA based technique.
\end{abstract}

Keywords: petroleum deposits, bacterial communities, ARDRA and sequencing
Volume I Issue I - 2014

\author{
Debarati Paul, ${ }^{3}$ Jamie Scott,' Magan Green, ${ }^{2}$ \\ Lewis R Brown, ${ }^{2}$ Mark L Lawrence' \\ 'College of Veterinary Medicine, Mississippi State University, \\ USA \\ ${ }^{2}$ Biological Sciences, Mississippi State University, USA \\ ${ }^{3}$ Amity Institute of Biotechnology, Amity University, India
}

Correspondence: Mark L Lawrence, College of Veterinary Medicine, Mississippi State University, Mississippi State, MS39762, USA Email lawrence@cvm.msstate.edu

Received: April 14, 20I4| Published: April 24, 2014

\section{Introduction}

Bacteria can exist under high pressure and temperature conditions, in low oxygen or low nutrient conditions, and sometimes are able to remain dormant for several years. Oilfields usually represent extreme environments, poor in nitrates and oxygen, but harbor a diverse community of sulfate-reducing, methanogenic and fermentative bacteria, and hydrocarbon or oil-utilizing bacteria. Some of the important edaphoclimatic factors that influence microbial community composition and diversity include $\mathrm{pH},{ }^{1}$ particle size, ${ }^{2}$ organic carbon, ${ }^{3}$ nitrogen/phosphate, ${ }^{4}$ water, ${ }^{5}$ and oxygen. ${ }^{6}$ The physiology and metabolic potential of microbial communities will vary greatly with location along a soil profile depending on the available water, plant derived resources (carbon, nitrogen, and other nutrients), mineralizable carbon and nitrogen, and oxygen. In mines and subsurface soils, these factors cause selective pressures that tend to decide the nature and distribution of bacteria, especially oxygen/nutrient limitations and temperature/pressure. ${ }^{7}$ The most widely represented and bestknown types are sulfate-reducing, methanogenic, and fermentative bacteria. $^{8-11}$

Some of the bacteria in mines and petroleum deposits survive the extreme environment by maintaining a dormant state. ${ }^{8}$ These bacteria tend to behave like oligotrophic bacteria ${ }^{10}$ or unculturable bacteria when grown in lab conditions because of long-term starvation conditions. Oligotrophic bacteria are slow-growing and ubiquitously occur in water or soil lacking organic substances.

To explore bacterial diversity in various environments/niches, 16S rRNA amplification and sequencing methods are commonly and efficiently used. ${ }^{12-15}$ Amplified ribosomal DNA restriction analysis (ARDRA $)^{12}$ is one of the simplest and most cost-effective techniques for culture-independent description of bacterial communities. ${ }^{16}$ For several environmental samples such as soil or seawater, the proportion of cells that can be cultured is estimated to be $0.1 \%$ or at most $10 \%$ of the total population, ${ }^{17}$ and few data are available concerning how closely they reflect the actual composition of these communities. ARDRA allows 'genetic fingerprinting' of the bacterial community dwelling in any particular environment and thereby provides a global picture of the genetic structure of the bacterial community.

Identification and quantification of petroleum reservoir microorganisms, including nitrate reducing bacteria (NRB) and sulfate reducing bacteria (SRB), has been assessed by cultivationdependent methods, ${ }^{18}$ and cultivation-independent methods have only recently been introduced into the field of reservoir microbiology. ${ }^{19,20}$ Considering the small number of these studies, information currently available on the microbial communities present in oil reservoirs is sparse and, most notably, the microbial diversity of drilling sample cores has never been studied before, probably due to lack of accessibility and difficulties in extracting bacteria/DNA from them. Most of the research so far dealt with production water from oil fields, oil dumps, or from the vicinity of oil..$^{19,21-23}$

In the current study, we evaluated the microbial diversity directly from cores taken from an active oil well. This research is a good example of collaborative efforts between academia and industry. As a result of this study, we isolated and identified some of the hydrocarbon utilizing oligotrophic bacteria in petroleum reservoirs. This study required developing methods for bacteria and DNA extraction from petroleum core samples, and to our knowledge it is the first report to use culture independent study of bacterial communities from petroleum communities using ARDRA and sequencing. We intend to compare our results with similarly deciphered communities from other core samples (varying depths and regions) in the future.

\section{Materials and methods}

\section{Sample collection}

Cores were obtained from approximately $700 \mathrm{~m}$ below surface in an oil-bearing formation in Brookhaven, Alabama. Each core was stored in a BBL Gaspak container to keep it in anaerobic conditions at low temperatures $\left(0-4^{\circ} \mathrm{C}\right)$. Each core was cut into 4 inch sections using sterile steel under an atmosphere of nitrogen. The center of the core was placed in a sterile stainless steel crusher and then sieved. 


\section{DNA extraction from the core samples}

DNA was isolated directly from crushed core for metagenomic analysis. The PowerMax Soil DNA Isolation Kit (Mo Bio Laboratories, Carlsbad, CA) was adapted for use with a Barocycler (Pressure Biosciences, South Easton, MA). One gram of the crushed core material was vortexed with Power Bead buffer then mixed with lysis buffer and vortexed. The PCT (Pressure Cycling Technology) tube was loaded into the PCT machine and run for 80 cycles $(35 \mathrm{kpsi}$ for $20 \mathrm{sec}$, atmospheric pressure $5 \mathrm{sec}$ ). This helped in lysis of the bacteria using high pressure. DNeasy spin column (QIAGEN) was used to purify the DNA from cell debris. The DNA was quantified and diluted with water for PCR.

\section{PCR and cloning}

Universal primers 27F (E. coli numbering 8 27; 5'-AGAGTTTGATCMTGGCTCAG-3') and 1492R (E. coli numbering 1492 1510; 5'-GGTTACCTTGTTACGACTT-3') (Cheneby et al., 2000) were used for amplification of bacterial 16S rRNA genes. PCR amplification of nearly $\sim 500 \mathrm{bp}$ of $16 \mathrm{~S}$ rRNA gene was performed in $25 \mu$ reaction mixtures. Reaction tubes contained 25 ng DNA, 1UTaq DNA Polymerase (New England Biolabs, Beverly, MA), 1 Xbuffer (10mM Tris- $\mathrm{HCl}$ [pH 9.0], $1.5 \mathrm{mM} \mathrm{MgCl}, 500 \mathrm{mM}$ $\mathrm{KCl}, 10 \mathrm{mM}$ deoxynucleoside triphosphate, and $20 \mathrm{pmol}$ of each primer $\mathrm{ml}^{-1}$. Initial DNA denaturation and enzyme activation steps were performed at $95^{\circ} \mathrm{C}$ for $30 \mathrm{~s}$, annealing at $50^{\circ} \mathrm{C}$ for $1 \mathrm{~min}$, and extension at $72^{\circ} \mathrm{C}$ for $2 \mathrm{~min}$, with a final extension for $10 \mathrm{~min}$ at $72^{\circ} \mathrm{C}$. The presence and yield of PCR product was monitored by $1 \%$ agarose gel electrophoresis at $200 \mathrm{~V}$ for $1 \mathrm{~h}$ in $1 \mathrm{X}$ Tris-acetate-EDTA buffer and stained with GELSTAR.

16S rRNA gene clone libraries were constructed for elucidating the bacterial population in the cores. For this purpose, 16S rRNA gene amplicons from five independent PCRs were pooled, ligated into the TOPO 2.1 plasmid vector (Invitrogen, Life technologies, CA) and transformed into Escherichia coli DH5 $5 \alpha-\mathrm{T} 1^{\mathrm{R}}$ chemically competent cells according to the manufacturer's instructions. The transformed cells were plated on Luria-Bertani agar plates containing $100 \mathrm{mg}$ $\mathrm{ml}^{-1}$ ampicillin, 40 $\mathrm{mg} \mathrm{ml}^{-1}$ isopropyl-b-D-thiogalactopyranoside, and $40 \mathrm{mg} \mathrm{ml}^{-1}$ 5-bromo-4-chloro-3-indolyl-b-D-galactoside. White clones were cultivated to analyze their plasmid content, and about 200 bacterial clones containing inserts of the correct size $(1.5 \mathrm{~kb})$ were stored in $10 \%$ glycerol at $-80^{\circ} \mathrm{C}$.

\section{ARDRA and sequencing}

Two restriction enzymes (RsaI and Sau3A) were selected for digestion of the clones based on in-silica digestion profile of a few clones. Digestions were performed for $4 \mathrm{~h}$ at $37^{\circ} \mathrm{C}$ in $25 \mu 1$ reaction volumes containing $10 \mu \mathrm{l}$ of the PCR product solution, $2.5 \mu \mathrm{l}$ of the incubation buffer (1X) and $0.3 \mu$ of the restriction enzyme (New England Biolabs). The reaction products were run on a $2 \%$ agarose gel, and the restriction pattern of the clones was compared.

Various phylotypes were identified on the basis of similarity in the restriction digestion pattern of 192 bacterial clones. Rarefaction analysis ${ }^{24}$ was used to confirm that the number of clone types had been exhausted after screening all the individual bacterial clones. We are aware that any given RFLP pattern may represent sequences from multiple phylogenetic groups and may therefore not represent a true phylotype in the traditional sense. Therefore, we use the term phylotype to indicate groups for richness calculations. Phylotype richness (S) was calculated as the total number of distinct RFLP patterns in a core. The Shannon-Weiner diversity index ${ }^{25}$ was calculated as follows: $\mathrm{H}=\mathrm{S}(\mathrm{ri})(\log 2 \mathrm{r} i \mathrm{i})$, where $\mathrm{r}$ represents the proportion of a distinct RFLP pattern relative to the sum of all distinct patterns. Evenness was calculated from the Shannon-Weiner diversity index: $\mathrm{E}=\mathrm{H} / \mathrm{Hmax}$ where Hmax $=\log 2(\mathrm{~S})$. Partial 16S rRNA gene sequences (at least 400 $\mathrm{bp)}$ of one representative member of each phylotype were obtained using M13F primer with the ABI PRISM Big Dye Terminator Cycle Sequencing kit and an ABI 310 automated DNA sequencer (Applied Biosystems, Foster City, CA). These sequences were used to construct phylogenetic trees to understand phylogenetic relations between the phylotypes.

\section{Data analysis}

Partial 16S rRNA gene sequences were initially analyzed using BLAST search (www.ncbi.nlm.nih.gov/blast/blast.cgi) and RDPII analysis software (www.ce.msu.edu/RDP/html/analyses.html). The sequences were submitted to the NCBI (National Centre for Biotechnology and Biotechnology Information), and GenBank accession numbers were obtained for all of them. The closest match and GenBank accession numbers of each sequence are listed in Table $1 \& 2$. Clustal $X^{26}$ was used to align these sequences. Sequence dissimilarities were converted to evolutionary distances according to the method of Jukes and Cantor (1969). Dendrograms were constructed with a neighbor-joining algorithm using NJ PLOT. ${ }^{27}$

\section{Culturing some of the aerobic microorganisms (oligotrophs) for identification}

Fifty grams of crushed core material was suspended in simulated production water, ${ }^{28}$ thoroughly mixed, and streaked on either BactoTryptic Soy Agar (TSA) or Bacto-Plate Count Agar prepared with simulated production water containing the following per 8 liters of distilled water $\left(\mathrm{NaCl} 778.00 \mathrm{~g}, \mathrm{Na}_{2} \mathrm{SO}_{4} 130.00 \mathrm{~g}, \mathrm{MgCl}_{2} .6 \mathrm{H}_{2} \mathrm{O} 352.00 \mathrm{~g}\right.$, $\mathrm{CaCl}_{2} .2 \mathrm{H}_{2} \mathrm{O} 36.00 \mathrm{~g}, \mathrm{KCl} 11.00 \mathrm{~g}, \mathrm{Na}_{2} \mathrm{HCO}_{3} 3.20 \mathrm{~g}, \mathrm{KBr} 1.60 \mathrm{~g}$, $\mathrm{SnCl}_{2} .6 \mathrm{H}_{2} \mathrm{O} 0.67 \mathrm{~g}, \mathrm{H} 3 \mathrm{BO} 30.41 \mathrm{~g}, \mathrm{Na}_{2} \mathrm{SiO}_{3} .9 \mathrm{H}_{2} \mathrm{O} 0.08 \mathrm{~g}, \mathrm{NaF} 0.05 \mathrm{~g}$, $\mathrm{NH}_{4} \mathrm{NO}_{3} 0.03 \mathrm{~g}, \mathrm{FePO}_{4} \cdot 4 \mathrm{H}_{2} \mathrm{O} 0.02 \mathrm{~g}$ ). Plates were also streaked on oil agar that was prepared with simulated production water supplemented with $0.1 \% \mathrm{KNO}_{3}, 0.37 \% \mathrm{~K}_{2} \mathrm{HPO}_{4} \cdot 3 \mathrm{H}_{2} \mathrm{O}, 1 \%$ filter-sterilized crude oil, and $2 \%$ Bacto-Agar. After the agar had been poured into a petri plate and allowed to harden, a thin overlay was added using oil agar prepared with oil-saturated water, but containing no added oil. After incubation, colonies picked into simulated production water, thoroughly mixed, and re-streaked on the same agar from which the colony came. After incubation, a single colony was picked onto an agar slant of the same agar from which the colony was obtained and incubated at $30^{\circ} \mathrm{C}$ until growth was evident. An appropriate control (without core material) was also serially diluted and plated. Pure individual colonies were picked up and stored at $-80^{\circ} \mathrm{C}$ as glycerol stocks. Some petri plates were poured with $16 \%$ bacto agar containing $1 / 8 \mathrm{~K}^{\text {th }}$ TSA for growing oligotrophs/bacteria that would only grow under low levels of nutrients.

Genomic DNA was isolated from cultured isolates using Wizard genomic DNA purification kit (Promega). DNA was run on $0.7 \%$ agarose gel, quantified, and used for PCR amplifications. For identification of bacterial colonies, the same PCR primers described for metagenomic analysis (universal primers $27 \mathrm{~F}$ and $1492 \mathrm{R}$ ) were used for amplification of bacterial 16S rRNA genes. The same PCR conditions were used as described above. The presence and yield of PCR product was monitored by $1 \%$ agarose gel electrophoresis. 


\section{Results and discussion}

\section{Microbial diversity and ARDRA}

DNA isolation from the cores was possible using the Barocycler (Pressure Biosciences) and the method described (Figure 1). This DNA was diluted 10times to obtain amplification using the universal primers as described. About 192 clones were screened for bacteria, out of which 156 showed the presence of $16 \mathrm{~S}$ rRNA gene inserts. Based on the clarity of banding patterns with Sau3AI, HaeIII, and RsaI, Sau3AI digestion profiles were used for identifying the 25 distinct phylotypes in bacteria. Rarefaction analysis curve (Figure 2) indicated that the population diversity has been sufficiently covered. For this community, a Shannon's diversity index $(\mathrm{H})$ was calculated of 3.61 and species evenness (E) of 77.7. The evenness values approximate the maximum possible values, as most of the sequence types were recovered only once. Representative members of each phylotype were partially sequenced, and a phylogenetic tree was constructed (Figure 3) to show the relationships among the various phylotypes. The affiliation of clone sequences to described taxa indicate the presence of mainly aerobic species belonging to Proteobacteria, although not always deducible with a high degree of confidence. Thirty-six clones did not have $16 \mathrm{~S}$ gene and were chimeric or false positives.

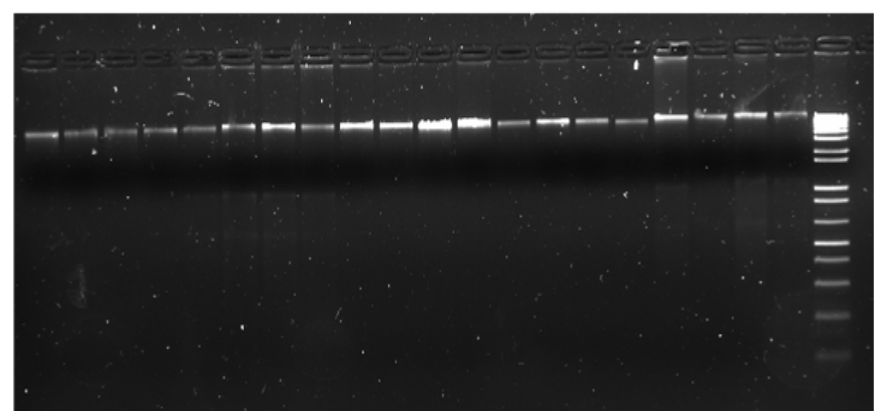

Figure I Isolation of metagenomic DNA from crushed cores using a technique developed in our lab. The last well in the gel shows the DNA ladder I kb plus.

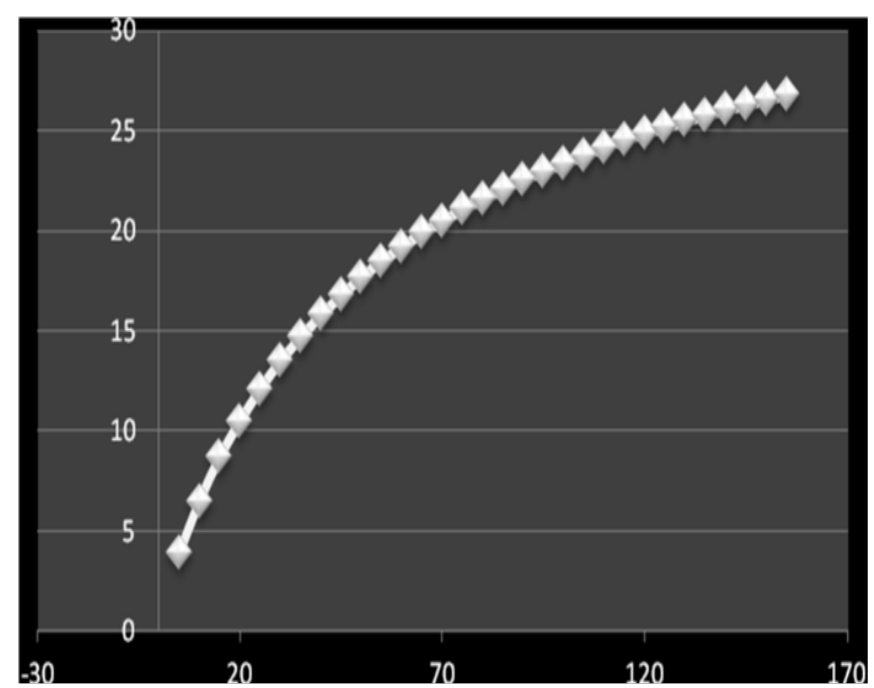

Figure 2 Rarefaction curve (no. of clones analyzed vs no. of phylotypes) indicating sufficient representation of bacterial diversity after screening about 200 clones. Clones were grouped as phylotypes on the basis of their RFLP pattern.

Various types of Alphaproteobacteria were abundant (67\%) (Figure 4). These bacteria show high degree of identity to species existing in the Yellow Sea and microbial mats in hypersaline lakes. Presence and abundance of marine/aquatic bacteria is interesting because it might indicate their tolerance to high pressure conditions and extreme environments. Some bacteria from hypersaline lakes might be involved in exopolymer degradation (unpublished results). Some species identified are similar to endosymbionts or gut bacteria of insects. Also bacteria similar to those found in Panda feces indicate their capability to degrade plant material, possibly contributing toward petroleum formation. Caulobacter sp. was detected, which are prosthecate bacteria often specialized for oligotrophic environments. ${ }^{29}$

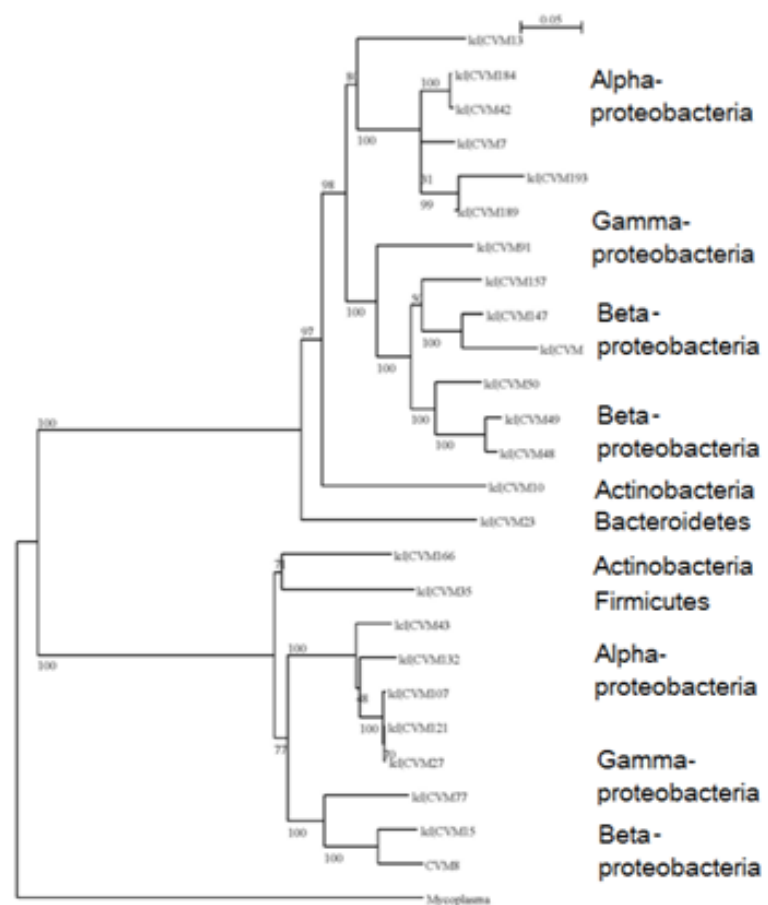

Figure 3 Dendrogram showing the phylogenetic relationships between various bacterial phylotypes. Bootstrapping values indicate the strength of each node. Distance scale indicates evolutionary distance. Mycoplasma has been used as the out group to root the tree.

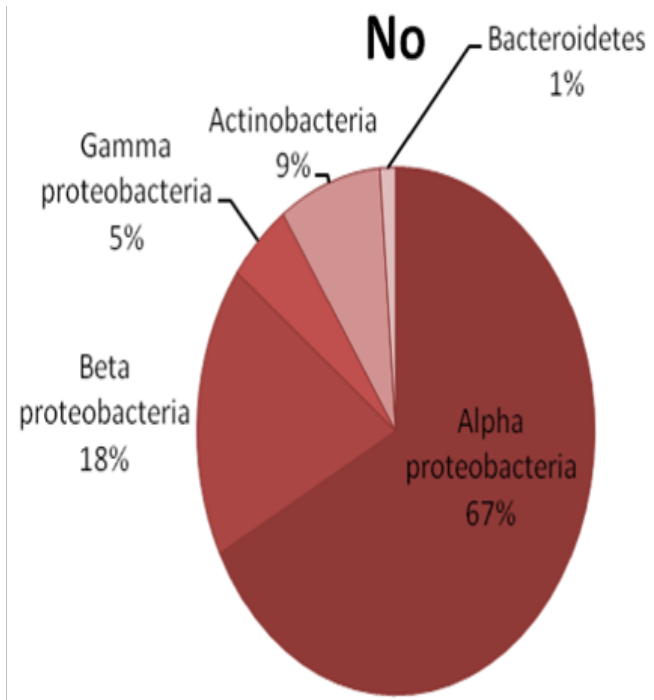

Figure 4 Pie chart showing the profile of bacterial species in the core population. 
Gammaproteobacteria and some Actinobacteria were detected along with a few unculturable species similar to those found in activated sludge or areas of heavy metal (uranium) contamination, which can also be extreme environments with high selective pressures. Presence of hydrocarbon- degrading Actinobacteria has been reported in soil collected from the vicinity of active oil wells and oil dumps. ${ }^{22,30-32}$ Strains similar to composting bacteria and those similar to lactic acid producing bacteria indicate anaerobic reducers.

Apart from these, iron reducers (Bacteroidetes, Gammaproteobacteria) and nitrate reducers (Betaproteobacteria, Gammaproteobacteria) were found, which is similar to previous reports. ${ }^{14,33}$ Some sulfate reducing bacteria and fermentative bacteria were also detected in our study but in comparatively lower percentages, which might be related to the conditions in the reservoir or isolation technique.

Schlegelella sp. and Tepidimonas spp. were the only hyperthermophilic strains detected in the population. Some species of the genus Schlegelella have been found to degrade poly (3-hydroxybutyrate) in a few cases via a thermotolerant PHB polymerase enzyme. ${ }^{34,35}$ Tepidimonas spp. is a slightly hyperthermophilic bacterium having optimal growth temperature of about $50-55^{\circ} \mathrm{C}$; some strains of this genus are known to produce useful proteases..$^{36,37}$ Another important beta proteobacterium identified in our study belonged to Leptothrix spp (obligate lithotroph), which is also called "iron bacteria" because of its importance in biological oxidation of iron and manganese. ${ }^{38,39}$ The obligate strains of Leptothrix are reported to grow on trace amounts of metal oxides ${ }^{38}$ and copiously produce extracellular sheaths encrusted with iron oxyhydroxides. The presence of this genus in petroleum deposits indicates the presence of oxides of $\mathrm{Fe}$ or $\mathrm{Mn}$ in trace amounts.

The phylogenetic tree Figure 3 shows two major groups/clades, both of which have Alpha-, Beta-, and Gammaproteobacteria distributed according to their phylogenetic proximity. This indicates that the phylotypes within any of the broad class (e.g. Alphaproteobacteria) are widely divergent and might be comprised of novel species of microorganisms.

\section{Microbial diversity amongst the cultured strains}

Using oil agar as media, we distinguished 9 different bacterial isolates and cloned their $16 \mathrm{~S}$ rDNA in $E$. coli for sequencing. It is probable that these strains were mostly surviving in an oligotrophic form ${ }^{40}$ and could be cultured only in $1 / 8 \mathrm{~K}^{\text {th }}$ diluted TSB agar instead of the normal concentration. Table 1 lists all the species that were cultured either aerobically or anaerobically. BLAST results showed that mainly the clones showed a high degree of $16 \mathrm{~S}$ rDNA sequence based on identity to Bacillus sp. or Paenibacillus sp. and Pseudomonas $\mathrm{sp}$. These bacteria commonly occur in soil rhizospheres. Interestingly, BS65 was strongly identical to P. strutzeri strains isolated from production water of oil reservoirs. Another isolate BS67 might be a Pseudomonas strain showing strong identity to uncultured bacteria found in reservoirs. Cho \& Giovannoni ${ }^{41}$ revealed that sporadically detected Gamma proteobacteria gene clones from seawater are part of a phylogenetically diverse constellation of organisms mainly composed of oligotrophic and ultra microbial lineages that are culturable under specific cultivation conditions. ${ }^{41}$ Pseudomonas is a member of Gammaproteobacteria, and there is definite evidence of ultramicrobial Pseudomonas lineages occurring in core samples. ${ }^{42}$ Kim \& Crowley ${ }^{43}$ studied the microbial diversity in ca. 28,000-yearold samples of natural asphalts from the Rancho La Brea Tar Pits in Los Angeles, CA and found that the predominant bacteria in both pits were Gammaproteobacteria including Xanthomonadaceae (5 clones) and Pseudomonadaceae (5 clones). Culturing on 10\% TSA plates showed the presence of yielded five distinct isolates of Pseudomonas spp., eight isolates of Bacillus spp., and five isolates of Citrobacter spp. ${ }^{43}$ Therefore, these results are also in accordance with our findings with regard to the uncultivable and cultural microbial diversity, where cultivable strains (on $10 \%$ TSA) were represented by relatively few strains. However, we found Paenibacillus sp. instead of Citrobacter spp.

Three of the strains belong to the genus Paenibacillus; BS81A shows strong sequence identity to $P$. favisporus, which has xylanophytic characteristics. P. favisporus sp. nov. produces a wide variety of hydrolytic enzymes, such as xylanases, cellulases, amylases, gelatinase, urease and $\beta$-galactosidase. This species might have helped in the formation of oil from plant residues. Presence of oligotrophic Bacillus sp. is expected ${ }^{44}$ because they secrete a large amount of mucus and have a viscid capsule or thick pectic exine around themselves to survive extremities. Polyphasic identification and characterization of these isolates are currently underway. We are also trying to isolate several other species on other media with the goal to understand carbon/nirogen cycling and metabolic capabilities of bacteria prevailing in the reservoirs.

Table I Partial I6S rDNA sequences and GenBank numbers of some of the isolates from the petroleum deposit core material

\begin{tabular}{lllll}
\hline Isolate & Gen bank ID & Best hit BLAST ID & Identity \% & Match \\
\hline BS2 & JF963965 & JF322796 & 98 & Bacillus cereus \\
BS65 & JF963966 & HM030754 & 99 & P. strutzeri \\
BS67 & JF963967 & GU565237 & 99 & Pseudomonas sp. \\
BS67A & JF963968 & GQ15049I & 94 & Paenibacillus sp. $\mathrm{nC2}$ \\
BS7I & JF963969 & FJ8I748I & 92 & Bacillus sp \\
BS78 & JF963970 & JF7I4216 & 98 & Bacillus sp \\
BS29A & JF96397I & FR85I254 & 99 & Bacillus sp. PRI.7 \\
BS8IA & JF963972 & AY308758 & 99 & Paenibacillus faviospores \\
BS66A & JF963973 & EU368479 & 99 & Paenibacillus \\
\hline
\end{tabular}


Table 2 GenBank accession numbers of representative clones for each phylotype along with GenBank IDs of the closest BLAST hit and \% identity

\begin{tabular}{|c|c|c|c|c|c|}
\hline Rep-clone & Gen bank no. & No. of Clones & Identification & Closest hit BLAST ID & Identity \% \\
\hline CVMbac7 & JF922889 & 10 & Caulobacter sp & FJ8705I9 & 99 \\
\hline CVMbac8 & JF922913 & I & B proteobacterium & HQ823674 & 99 \\
\hline CVMbaclo & JF922890 & 2 & Propionibacteria & HQ585I78 & 99 \\
\hline CVMbacl3 & JF92289I & 56 & Sphingomonas sp. & HM057723 & 99 \\
\hline CVMbacl 5 & JF922892 & 6 & Schlegelella sp & FN66726I & 99 \\
\hline CVMbac23 & JF922893 & 2 & Flavobacterium & FR691516 & 99 \\
\hline CVMbac35 & JF922895 & 7 & Streptococcus suis & AY7533I5 & 98 \\
\hline CVMbac27 & JF922894 & 14 & alpha proteobacterium & HM480I75 & 98 \\
\hline CVMbac42 & JF922896 & 7 & alpha proteobacterium & EU429493 & 99 \\
\hline CVMbac48 & JF922898 & I & Tepidimonas sp & EU450347 & 48 \\
\hline CVMbac43 & JF922897 & I & Phenylobacterium & JF202879 & 98 \\
\hline CVMbac49 & JF922899 & 2 & beta proteobacterium & EU4503 I4 & 98 \\
\hline CVMbac50 & JF922900 & 9 & Pseudomonas sp & HQ660803 & 99 \\
\hline CVMbac77 & JF92290I & 2 & Gamma proteobacterium & FR774582 & 100 \\
\hline CVMbac9l & JF922902 & 6 & Gamma proteobacterium & DQ230964 & 99 \\
\hline CVMbacl07 & JF922903 & 5 & alpha proteobacterium & HMII 0470 & 99 \\
\hline CVMbacl93 & JF922912 & I & alpha proteobacterium & EUI 48878 & 92 \\
\hline CVMbacl2I & JF922904 & I & alpha proteobacterium & HM480264 & 99 \\
\hline CVMbacl 32 & JF922905 & 3 & alpha proteobacterium & HM799072 & 97 \\
\hline CVMbacl 57 & JF922908 & 6 & beta proteobacterium & EF64809I & 100 \\
\hline CVMbacl66 & JF922909 & 4 & Actinobacterium & JF346422 & 99 \\
\hline CVMbacl 84 & JF922910 & 3 & alpha proteobacterium & AY293404 & 99 \\
\hline CVMbacl 35 & JF922906 & 2 & Schlegelella sp & HM3I6462 & 91 \\
\hline CVMbacl 47 & JF922907 & I & Leptothrix sp & HMI8682I & 100 \\
\hline CVMbacl89 & JF9229II & 4 & alpha proteobacterium & EF658677 & 99 \\
\hline
\end{tabular}

\section{Conclusion}

The majority of studies in petroleum microbiology have been conducted using samples of formation water or water-oil mixtures. Only one study reported in the literature used crude oil from petroleum reservoir to analyze microbial communities. ${ }^{45} \mathrm{We}$ isolated DNA from core samples from a petroleum reservoir, and to our knowledge this is the first report of its kind.

Theabundance,composition, anddiversityofmicrobialcommunities within soils are strongly depth dependent. ${ }^{46}$ In this mesothermic core sample, we elucidated a wide range of bacteria. Alphaproteobacteria dominated the population and were similar to bacterial populations found in seawater and hypersaline lakes. The bacterial diversity is greater as compared to deeper high temperature oil reservoirs under seawater. ${ }^{19,33}$ However, Alpha-, Beta-, and Gammaproteobacteria are common classes found in both environments. Some of these microbial groups were shown to be exclusive of the biodegraded oil sample, such as the genera Acinetobacter, Bacillus, and Streptococcus. We found some bacteria showing similarity to Streptococcus sp. Presence of other oil degraders in the population as documented by Sette et al (2007) was not evident. In petroleum reservoirs, anaerobic conditions exist, and oil degradation is mainly mediated by methanogenesis. ${ }^{47}$ Therefore, we believe hydrocarbon utilization is the most important source of nourishment in petroleum deposits, although in some cases the microbes were lithotrophic and survived by utilizing the metal oxides present.

This study also shows that enrichment cultures did not elucidate most of the diversity in the core samples except for some Pseudomonas $\mathrm{sp}$. that were found by both culturing and direct sequencing. However, extraction of DNA from the hard core samples was difficult and required the use of special equipment (Barocycler, $\mathrm{PBI}$ ). There is the possibility of missing some bacterial species due to differential lysis and PCR biases. However, to decipher the entire microbial diversity of oil reservoirs, this method is necessary along with isolation from crude petroleum and production water. New approaches using highthroughput DNA sequencing will be our next step for obtaining insight into the function and diversity of oil inhabiting bacteria and the pathways for production/degradation of petroleum hydrocarbons.

\section{Acknowledgements}

None. 


\section{Conflict of interest}

The author declares no conflict of interest.

\section{References}

1. Eichorst SA, Breznak JA, Schmidt TM. Isolation and characterization of soil bacteria that define Terriglobus gen. nov., in the phylum Acidobacteria. Appl Environ Microbiol. 2007;73(8):2708-2717.

2. Sessitsch A, Weilharter A, Gerzabek MH, et al. Microbial population structures in soil particle size fractions of a long-term fertilizer field experiment. Appl Environ Microbiol. 2001;67(9):4215-4224.

3. Zhou J, Xia B, Treves DS, et al. Spatial and resource factors influencing high microbial diversity in soil. Appl Environ Microbiol. 2002;68(1):326-334.

4. Fierer N, Andrew A, Schimel JP, et al. Controls on microbial CO2 production: a comparison of surface and subsurface soil horizons. Global Change Biology. 2003;9(9):1322-1332.

5. Treves DS, Xia B, Zhou J, et al. A two-species test of the hypothesis that spatial isolation influences microbial diversity in soil. Microb Ecol. 2003;45(1):20-28.

6. Ludemann H, Arth I, Liesack W. Spatial changes in the bacterial community structure along a vertical oxygen gradient in flooded paddy soil cores. Appl Environ Microbiol. 2000;66(2):754-762.

7. Urbanova M, Kopecky J, Valaskova V, et al. Development of bacterial community during spontaneous succession on spoil heaps after brown coal mining. FEMS Microbiol Ecol. 2011;78(1):59-69.

8. Miteva VI, Brenchley JE. Detection and isolation of ultrasmall microorganisms from a 120,000-year-old greenland glacier ice core. Appl Environ Microbiol. 2005;71(12):7806-7818.

9. Pavissich JP, Silva M, Gonzalez B. Sulfate reduction, molecular diversity, and copper amendment effects in bacterial communities enriched from sediments exposed to copper mining residues. Environ Toxicol Chem. 2010;29(2):256-264.

10. Tada Y, Ihmori M, Yamaguchi J. Oligotrophic bacteria isolated from clinical materials. J Clin Microbiol. 1995;33(2):493-494.

11. Voordouw G. Production-related petroleum microbiology: progress and prospects. Curr Opin Biotechnol. 2011;22(3):401-405.

12. Gich FB, Amer E, Figueras JB, et al. Assessment of microbial community structure changes by amplified ribosomal DNA restriction analysis (ARDRA). Int Microbiol. 2000;3(2):103-106.

13. Lagace L, Pitre M, Jacques $M$, et al. Identification of the bacterial community of maple sap by using amplified ribosomal DNA (rDNA) restriction analysis and rDNA sequencing. Appl Environ Microbiol. 2004;70(4):2052-2060.

14. Sette LD, Simioni KC, Vasconcellos SP, et al. Analysis of the composition of bacterial communities in oil reservoirs from a southern offshore Brazilian basin. Antonie Van Leeuwenhoek. 2007;91(3):253-266.

15. Urakawa H, Kita-Tsukamoto K, Ohwada K. Microbial diversity in marine sediments from Sagami Bay and Tokyo Bay, Japan, as determined by 16S rRNA gene analysis. Microbiology. 1999;145(Pt 11):3305-3315.

16. Ranjard L, Poly F, Nazaret S. Monitoring complex bacterial communities using culture-independent molecular techniques: application to soil environment. Res Microbiol. 2000;151(3):167-177.

17. Amann RI, Ludwig W, Schleifer KH. Phylogenetic identification and in situ detection of individual microbial cells without cultivation. Microbiol Rev. 1995;59(1):143-169.
18. Telang AJ, Ebert S, Foght JM, et al. Effect of nitrate injection on the microbial community in an oil field as monitored by reverse sample genome probing. Appl Environ Microbiol. 1997;63(5):1785-1793.

19. Gittel A, Sorensen KB, Skovhus TL, et al. Prokaryotic community structure and sulfate reducer activity in water from high-temperature oil reservoirs with and without nitrate treatment. Appl Environ Microbiol. 2009;75(22):7086-7096

20. Li H, Yang SZ, Mu BZ, et al. Molecular phylogenetic diversity of the microbial community associated with a high-temperature petroleum reservoir at an offshore oilfield. FEMS Microbiol Ecol. 2007;60(1):74 84.

21. Liu YJ, Chen YP, Jin PK, et al. Bacterial communities in a crude oil gathering and transferring system (China). Anaerobe. 2009;15(5):214 218

22. Zeinali M, Vossoughi M, Ardestani SK, et al. Hydrocarbon degradation by thermophilic Nocardia otitidiscaviarum strain TSH1:physiological aspects. J Basic Microbiol. 2007;47(6):534-539.

23. Zhang L, An R, Wang J, et al. Exploring novel bioactive compounds from marine microbes. Curr Opin Microbiol. 2005;8(3):276-281.

24. Tipper JC. Rarefaction and rarefiction- the use and abuse of a method in paleoecology. Paleobiology. 1979;5(4):423-434.

25. Margalef R. Information theory in ecology. General Systems. 1958;3:36.

26. Thompson JD, Gibson TJ, Plewniak F, et al. The CLUSTAL_X windows interface:flexible strategies for multiple sequence alignment aided by quality analysis tools. Nucleic Acids Res. 1997;25(24):4876-4882.

27. Perriere G, Gouy M. WWW-query:an on-line retrieval system for biological sequence banks. Biochimie. 1996;78(5):364-369.

28. Azadpour A, Brown LR, Vadie AA. Examination of thirteen petroliferous formations for hydrocarbon-utilizing sulfate-reducing microorganisms. Journal of Industrial Microbiology. 1996;16(5):263-266.

29. Abraham WR, Strompl C, Meyer H, et al. Phylogeny and polyphasic taxonomy of Caulobacter species. Proposal of Maricaulis gen. nov. with Maricaulis maris (Poindexter) comb. nov. as the type species, and emended description of the genera Brevundimonas and Caulobacter. Int J Syst Bacteriol. 1999;49(Pt 3):1053-1073.

30. Zeinali M, Vossoughi M, Ardestani SK. Characterization of a moderate thermophilic Nocardia species able to grow on polycyclic aromatic hydrocarbons. Lett Appl Microbiol. 2007;45(6):622-628.

31. Zeinali M, Vossoughi M, Ardestani SK. Degradation of phenanthrene and anthracene by Nocardia otitidiscaviarum strain TSH1, a moderately thermophilic bacterium. J Appl Microbiol. 2008;105(2):398-406.

32. Zeinali M, Vossoughi M, Ardestani SK. Naphthalene metabolism in Nocardia otitidiscaviarum strain TSH1, a moderately thermophilic microorganism. Chemosphere. 2008;72(6):905-909.

33. Yamane K, Hattori $\mathrm{Y}$, Ohtagaki $\mathrm{H}$, et al. Microbial diversity with dominance of $16 \mathrm{~S}$ rRNA gene sequences with high GC contents at 74 and 98 degrees C subsurface crude oil deposits in Japan. FEMS Microbiol Ecol. 2011;76(2):220-235.

34. Elbanna K, Lutke-Eversloh T, Van Trappen S, et al. Schlegelella thermodepolymerans gen. nov., sp. nov., a novel thermophilic bacterium that degrades poly(3-hydroxybutyrate-co-3-mercaptopropionate). Int $J$ Syst Evol Microbiol. 2003;53(Pt 4):1165-1168.

35. Romen F, Reinhardt S, Jendrossek D. Thermotolerant poly(3hydroxybutyrate)-degrading bacteria from hot compost and characterization of the PHB depolymerase of Schlegelella sp. KB1a. Arch Microbiol. 2004;182(2-3):157-164. 
36. Albuquerque L, Tiago I, Verissimo A, et al. Tepidimonas thermarum sp. nov., a new slightly thermophilic betaproteobacterium isolated from the Elisenquelle in Aachen and emended description of the genus Tepidimonas. Syst Appl Microbiol. 2006;29(6):450-456.

37. Chen TL, Chou YJ, Chen WM, et al. Tepidimonas taiwanensis sp. nov., a novel alkaline-protease-producing bacterium isolated from a hot spring. Extremophiles. 2006;10(1):35-40.

38. Fleming EJ, Langdon AE, Martinez-Garcia M, et al. What's new is old:resolving the identity of Leptothrix ochracea using single cell genomics, pyrosequencing and FISH. PLoS One. 2011;6(1):e17769.

39. Veen van WL, Mulder EG, Deinema MH. The Sphaerotilus-Leptothrix group of bacteria. Microbiol Rev. 1978;42(2):329-356

40. Vartoukian SR, Palmer RM, Wade WG. Strategies for culture of 'unculturable' bacteria. FEMS Microbiol Lett. 2010;309(1):1-7.

41. Cho JC, Giovannoni SJ. Cultivation and growth characteristics of a diverse group of oligotrophic marine Gammaproteobacteria. Appl Environ Microbiol. 2004;70(1):432-440.

42. Lazar I, Petrisor IG, Yen TF. Microbial enhanced oil recovery (MEOR) Petroleum Science and Technology. 2007;25(11):1353-1366.
43. Kim JS, Crowley DE. Microbial diversity in natural asphalts of the Rancho La Brea Tar Pits. Appl Environ Microbiol. 2007;73(14):4579_ 4591 .

44. HuiXia P, ZhengMing C, XueMei Z, et al. A study on an oligotrophic bacteria and its ecological characteristics in an arid desert area. Science in China Series D:Earth Sciences. 2007;50(1):128-134

45. Tanaka Y, Sogabe M, Okumura K, et al. A highly selective direct method of detecting sulphate-reducing bacteria in crude oil. Lett Appl Microbiol. 2002;35(3):242-246.

46. Hansel CM, Fendorf S, Jardine PM, et al. Changes in bacterial and archaeal community structure and functional diversity along a geochemically variable soil profile. Appl Environ Microbiol. 2008;74(5):1620-1633.

47. Jones DM, Head IM, Gray ND, et al. Crude-oil biodegradation via methanogenesis in subsurface petroleum reservoirs. Nature. 2008;451(7175):176-180. 